\title{
PENGARUH MOTIVASI DAN SUASANA LINGKUNGAN KERJA TERHADAP KINERJA KARYAWAN PADA PT. BANK RAKYAT INDONESIA (Persero) Tbk. CABANG PANAKUKKANG MAKASSAR
}

\author{
Asilya Jacqlien \\ Institut Bisnis Dan Keuangan Nitro Makassar \\ Email: asilya200092@gmail.com
}

\begin{abstract}
Abstrak
Peneltian ini bertujuan untuk menganalisis dan mengetahui Pengaruh Motivasi dan Suasana Lingkungan Kerja Terhadap Kinerja Karyawan Pada PT. Bank Rakyat Indonesia (Persero) Tbk. Cabang Panakukkang Makassar. Berdasarkan hasil analisis menunjukkan bahwa motivasi kerja berpengaruh signifikan terhadap kinerja karyawan PT. Bank Rakyat Indonesia (Persero) Tbk. Cabang Panakukkang Makassar, begitu pun juga dengan suasana lingkungan kerja dan kinerja karyawan. Sampel dalam penelitian ini adalah karyawan PT. Bank Rakyat Indonesia (Persero) Tbk. Cabang Panakukkang Makassar sebanyak 30 karyawan.
\end{abstract}

Kata kunci: motivasi kerja, suasana lingkungan kerja, kinerja karyawan. 


\section{PENDAHULUAN}

Menurut Sutrisno (2010:3) Sumber daya manusia merupakan satu-satunya sumber daya yang memiliki akal perasaan, keingininan, keterampilan, pengetahuan, dorongan, daya, dan karya (rasio, rasa, dan karsa). Semua potensi SDM tersebut berpengaruh terhadap upaya organisasi dalam mencapai tujuan. Beberapapun majunya teknologi, perkembangan informasi, tersedianya modal dan memadainya bahan, jika tanpa SDM sulit bagi organisasi itu untuk mencapai tujuannya.

Dalam kondisi saat ini baik teknologi, politik, ekonomi sangat berpengaruh dalam menghadapi persaingan. Pada umumnya perusahaan yang tidak mampu menghadapai persaingan akan memiliki kinerja dan kualitas produk yang rendah. Manager harus bertanggung jawab untuk membuat rencana dan mimiliki kompetensi untuk melakukan perubahan sesuai dengan yang diharapkan. Kesuksesan suatu organisasi dalam mengelola sumber daya manusia yang dimiliki sangat menentukan kesuksesan dari pencapaian tujuan organisasi. Keberhasilan pencapaian organisasi sangat dipengaruhi oleh peran dan kinerja karyawannya, kinerja dalam suatu organisasi merupakan bukti dari berhasil tidaknya tujuan organisasi yang telah ditetapkan. Untuk meraih kinerja yang diharapkan faktor manusia merupakan variabel yang penting karena sukses tidaknya suatu usaha, bisanya ditentukan oleh perilaku manusia yang melaksanakan pekerjaan. 
Menurut Sondang P. Siagian (2008:138) Motivasi kerj merupakan daya pendorong yang mengakibatkan seorang karyawan yang mau dan rela untuk menggerakkan kemmapuan dalam membentuk keahlian dan keterampilan tenaga dan waktunya untuk menyelenggarakan berbagai kegiatan yang menjadi tanggung jawabnya dan menunaikan kewajibannya dalam rangka pencapaian tujuan dan berbagai sasaran perusahaan yang telah ditentukan sebelumnya.

Motivasi setiap karyawan tentu berbeda-beda tidak bisa disamakan. Motivasi kerja karyawan sebagian besar dipengaruhi oleh gaji dan karyawan yang menetap cukup lama akan memiliki motivasi yang tinggi dan karyawan yang masih kerja kontrak kinerja mereka dipengaruhi oleh beberapa faktor baik internal maupun eksternal.

Penilaian kinerja merupakan suatu proses organisasi dalam menilai unjuk kerja pegawainya. Tujuan dilakukannya penilaian kinerja secara umum adalah untuk memberikan feedback kepada pegawai dalam upaya memperbaiki tampilan kerjanya dan upaya meningkatkan produktivitas organisasi, dan secara khusus dilakukan dalam kaitannya dengan berbagai kebijaksanaan terhadap pegawai seperti untuk tujuan promosi, kenaikan gaji, pendidikan dan latihan. sehingga penilaian kinerja dapat menjadi landasan untuk penilaian sejauh mana kegiatan Sumber Daya Manusia (SDM) seperti perekrutan. seleksi.

\section{A. Rumusan Masalah}

1. Apakah motivasi dan suasana kerja sangat berpengaruh terhadap kinerja karyawan dan seberapa besar pengaruhnya pada Bank BRI Cabang Panakukkang Makassar? 


\section{B. Tujuan Penelitian}

Untuk mengetahui dan menganalisis pengaruh motivasi dan suasana lingkungan kerja terhadap kinerja karyawan pada Bank BRI Cabang Panakukkang Makassar.

\section{Kegunaan Penelitian}

1. Bagi penulis

Penelitian ini diharapkan dapat mengembangkan pengetahuan dan wawasan penulis dan merupakan suatu latihan teknis untuk membandingkan antara teori yang diperoleh selama masa perkuliahan dengan praktik yang sebenarnya, serta sebagai salaha satu syarat untuk menyelesaikan Studi S1 di jurusan Manajemen Perbankan.

2. Bagi masyarakat

Penelitian dalam skripsi ini diharapkan dapat menjadi salah satu bahan untuk menambah pengetahuan dan wawasan mengenai konsep, sistem perlakuan akuntansi dengan transaksi pemberian layanan jasa dan pembiayaan yang berperan penting bagi pertumbuhan ekonomi.

\section{TINJAUAN PUSTAKA}

\section{Motivasi}

\section{A. Pengertian Motivasi}

Motivasi berasal dari kata latin movere yang berarti dorongan, daya penggerak atau kekuatan yang menyebabkan suatu tindakan atau perbuatan. Kata movere, dalam bahasa inggris, sering disepadankan dengan motivation yang 
berarti pemberian motif, penimbulan motif, atau hal yang menimbulkan dorongan atau keadaan yang menimbulkan dorongan. Motivasi merupakan suatu dorongan yang membuat orang bertindak atau berperilaku dengan cara - cara motivasi yang mengacu pada sebab munculnya sebuah perilaku, seperti faktor - faktor yang mendorong seseorang untuk melakukan atau tidak melakukan sesuatu. Motivasi dapat diartikan sebagai kehendak untuk mencapai status, kekuasaan dan pengakuan yang lebih tinggi bagi setiap individu. Motivasi justru dapat dilihat sebagai basis untuk mencapai sukses pada berbagai segi kehidupan melalui peningkatan kemampuan dan kemauan. Selain itu motivasi dapat diartikan sebagai keadaan yang memberikan energi, mendorong kegiatan atau moves, mengarah dan menyalurkan perilaku kearah mencapai kebutuhan yang memberi kepuasaan atau mengurangi ketidakseimbangan.

Menurut Amstrong Motivasi bersumber dari dua dimensi yaitu: 1. Motivasi Ekstrinsik atau motivasi buatan (sesuatu yang dilakukan untuk memotivasi individu). 2. Motivasi intrisik atau motivasi hakiki (dorongan dari dalam individu).

a. Faktor- faktor Yang Mempengaruhi Motivasi

Motivasi sebagai proses psikologis dalam diri seseorang akan dipengaruhi oleh beberapa faktor. Faktor-faktor tersebut dapat dibedakan atas faktor internal dan eksternal yang berasal dari karyawan.

1) Faktor Internal Faktor internal yang dapat mempengaruhi pemberian motivasi pada seseorang antara lain:

a. Keinginan untuk dapat hidup, keinginan untuk dapat hidup meliputi memperoleh kompensasi yang memadai, pekerjaan 
tetap walaupun penghasilan tidak begitu memadai, kondisi kerja yang aman dan nyaman.

b. Keinginan untuk dapat memiliki, , keinginan untuk dapat memiliki sesuatu dapat mendorong seseorang untuk mau melakukan pekerjaan.

c. Keinginan untuk memperoleh penghargaan, seseorang mau bekerja disebabkan adanya keinginan untuk diakui, dihormati oleh orang lain, memperoleh status sosial yang lebih tinggi, dan nama baik.

d. Keinginan untuk memperoleh pengakuan, keinginan memperoleh pengakuan meliputi adanya penghargaan terhadap prestasi, adanya hubungan kerja yang kompak dan harmonis, serta pimpinan yang adil dan bijaksana.

e. Keinginan untuk berkuasa, keinginan berkuasa mendorong seseorang untuk bekerja lebih keras.

2) Faktor Eksternal Faktor external juga memiliki pengaruh pada motivasi yang meliputi sebagai berikut:

a. Kondisi lingkungan kerja, lingkungan kerja adalah keseluruhan sarana dan prasarana kerja yang ada disekitar karyawan yang dapat mempengaruhi pelaksanaan pekerjaan.

b. Kompensasi yang memadai, kompensasi yang memadai merupakan alat motivasi yang paling ampuh bagi perusahaan untuk mendorong para karyawan untuk bekerja lebih baik. 
c. Supervisi yang baik, fungsi supervisi dalam pekerjaan adalah memberikan pengarahan, membimbing kerja para karyawan, agar dapat melaksanakan kerja dengan baik tanpa membuat kesalahan.

d. Adanya jaminan pekerjaan, karyawan dapat bekerja dengan baik apabila perusahaan dapat memberikan jaminan kerier untuk masa depan baik, jaminan promosi jabatan, pangkat, maupun jaminan pemberian kesempatan pengembangan potensi diri.

e. Status dan tanggung jawab, dengan menduduki jabatan, orang merasa dirinya akan dipercaya, diberi tanggung jawab, dan wewenang yang besar untuk melakukan kegiatan.

f. Peraturan yang fleksibel, biasanya peraturan bersifat melindungi dan dapat memberikan motivasi karyawan untuk bekerja lebih baik

\section{SUASANA LINGKUNGAN KERJA}

\section{A. Pengertian Lingkungan Kerja}

Lingkungan kerja merupakan bagian komponen yang sangat penting di dalam karyawan melakukan aktivitas bekerja. Dengan memperhatikan lingkungan kerja yang baik atau menciptakan kondisi kerja yang mampu memberikan motivasi karyawan untuk bekerja, maka dapat membawa pengaruh terhadap semangat kerja karyawan. Faktor lingkungan kerja memiliki pengaruh secara langsung maupun tidak langsung terhadap peningkatan kinerja karyawan di dalam menyelesaikan tugas dan 
tanggung jawabnya saat melaksanakan pekerjaan yang pada akhirnya akan meningkatkan kinerjanya.

Menurut Nitisemito lingkungan kerja adalah segala sesuatu yang berada disekitar para pekerja/pegawai/karyawan yang dapat berpengaruh pada dirinya dalam melaksanakan kewajibannya sebagai karyawan. Menurut Henry Simamora lingkungan kerja adalah gambaran umum karyawan dan perubahannya membantu manajer spesialis sumber daya manusia untuk memeperkirakan tipe-tipe tenaga kerja yang dibutuhkan dan tersedia untuk bisa mencapai tujuan-tujuan organisasi.

B. Jenis-Jenis Lingkungan Kerja

1. Lingkungan kerja fisik

Lingkungan kerja fisik dapat di artikan semua keadaan yang ada disekitar tempat kerja, yang dapat mempengaruhi kinerja karyawan. Menurut Sedarmayanti (2009:22) yang dimaksud lingkungan kerja fisik yaitu semua keadaan berbentuk fisik yang terdapat disekitar tempat kerja dimana dapat mempengaruhi kerja karyawan baik secara langsung maupun tidak langsung. Sedangkan menurut Sumartono dan Sugito (2004:146) lingkungan kerja fisik adalah kondisi fisik dalam perusahaan disekitar tempat kerja, seperti sirkulasi udara, warna tembok, keamanan, ruang gerak dan lain-lain.

Lingkungan kerja fisik merupakan semua yang berada di sekitar pekerja atau karyawan yang mampu mempengaruhi dirinya ketika melaksanakan tugas-tugas yang telah dibebankan kepadanya dan 
dipengaruhi oleh fisik, biologis, fisiologis, kimia, mental, dan sosial ekonomi. Lingkungan kerja fisik yang baik akan membuat karyawan merasa nyaman dalam bekerja. Unsur-unsur lingkungan kerja fisik dari suatu perusahaan atau organisasi haruslah nyaman dan menyenangkan. Lingkungan kerja fisik dapat dibagi dalam dua kategori, yaitu: Lingkungan kerja yang berhubungan secara langsung dengan pekerja/karyawan, misalnya: pusat kerja, kursi, meja, ruangan, dan sebagainya. Lingkungan kerja perantara atau lingkungan kerja umum. Lingkungan kerja perantara dapat juga disebut lingkungan kerja yang dapat mempengaruhi kondisi manusia, misalnya: suhu, kelembaban, pencahayaan, sirkulasi udara, kebisingan, bau tidak sedap, warna, dan lain-lain.

2. Lingkungan kerja non fisik

Sedarmayanti (2009:31) dalam Rahmawanti,N.P (2014:3) lingkungan kerja nonfisik merupakan semua kondisi yang terjadi dan berkaitan dengan hubungan kerja, baik dengan sesama rekan kerja, bawahan, maupun atasan. Lingkungan kerja nonfisik ini juga merupakan lingkungan kerja yang tidak dapat diabaikan karena dapat mempengaruhi kinerja karyawan. Sugito dan Sumartono Lingkungan kerja nonfisik adalah suatu kondisi lain dari lingkungan kerja fisik yang berkaitan dengan hubungan kerja antara seluruh pekerja yang bekerja di perusahaan yang sama.

Kondisi yang diciptakan perusahaan terkait dengan lingkungan kerja non fisik meliputi suasana kekeluargaan, komunikasi yang baik antara 
atasan dengan bawahan dan pengendalian diri. Menurut Ahyari (2001:126) faktor lain dalam lingkungan kerja non fisik yang tidak boleh diabaikan adalah hubungan karyawan di dalam perusahaan yang bersangkutan tersebut. Dari beberapa penjelasan di atas dapat disimpulkan bahwa lingkungan kerja non fisik adalah kondisi lain dari lingkungan kerja fisik yang berkaitan dengan hubungan kerja karyawan yang dapat mempengaruhi kinerjanya. Berikut ini penjelasan mengenai unsur-unsur lingkungan kerja non fisik :

\section{Kinerja Karyawan}

A. Pengertian kinerja karyawan

Dalam mencapai tujuannya setiap organisasi di pengaruhi perilaku organisasi. Salah satu kegiatan yang paling lazim di lakukan dalam organisasi adalah kinerja karyawan, yaitu bagaimana ia melakukan segala sesuatu yang berhubungan dengan sesuatu pekerjaan atau peranan dalam organisasi. Pengertian kinerja atau performance merupakan gambaran mengenai tingkat pencapaian pelaksanaan suatu program kegiatan atau kebijakan dalam mewujudkan sasaran, tujuan visi dan misi organisasi yang di tuangkan melalui perencanaan strategi suatu organisasi.

Ruky (2006:15) dalam Daga (mengemukakan bahwa : "Kinerja adalah catatan tentang hasil-hasil yang diperoleh dari fungsi-fungsi pekerjaan atau kegiatan tertentu selama kurun waktu tertentu". Fungsi pekerjaan atau kegiatan yang dimaksud disini adalah 
pelaksanaan hasil pekerjaan atau kegiatan seseorang atau kelompok yang menjadi wewenang dan tanggung jawabnya dalam suatu organisasi.

Menurut Daga (2021:2) faktor yang sangat umum dan hamper selalu dikaji dalam penilaian kinerja adalah faktor peran kepemimpinan dan pengembangan sumber daya manusia. Kepemimpinan dan pengembangan sumber daya manusia diharapkan mampu menciptakan kepuasan kerja karyawan. Kepuasan kerja karyawan yang dirasakan akan menimbulkan motivasi untuk menghasilkan kinerja karyawan yang diharapkan.

B. Faktor yang Harus di Perhatikan dalam Penilaian Kinerja Karyawan

\section{- Kuantitas Kerja}

Kinerja karyawan dapat dipandang sebagai kuantitas kerja. Intinya adalah berapa banyak pekerjaan yang dapat dilakukan dalam waktu yang paling efektif dan efisien.

\section{- Kualitas Kerja}

Kualitas yang ditunjukkan di sini adalah seberapa benar dan memuaskan pekerjaan Anda. Kualitas ini berbanding lurus dengan proses pelaksanaan pekerjaan karyawan. Ini dapat didukung oleh ketentuan pedoman yang jelas oleh kepala delegasi kerja. 


\section{- Pemahaman Tentang Pekerjaan}

Pengetahuan dan keterampilan adalah hal yang sangat penting yang dimiliki karyawan terkait dengan kinerja mereka dalam suatu pekerjaan. Pengetahuan di tempat kerja dapat dilihat dari latar belakang pendidikan karyawan serta dari pengetahuan yang dapat diberikan perusahaan melalui pelatihan dan platform digital untuk meningkatkan kinerja karyawan.

\section{- Membuat Perencanaan Kegiatan}

Rencana ini juga dapat digunakan untuk mengevaluasi kinerja karyawan. Selain itu, perencanaan tidak hanya melayani profesionalisme, tetapi juga dapat digunakan sebagai referensi pribadi untuk seseorang yang menggunakan rencana pengembangan pribadi dan menetapkan tujuan pribadi. Ini penting untuk mengukur kemajuan sumber daya manusia yang bersangkutan. Dan data dari departemen SDM ketika mengevaluasi pekerjaan individu serta pelatihan dan sistem lainnya di perusahaan.

C. Faktor-faktor yang Mempengaruhi Kinerja Karyawan
a. Efektifitas dan Efisiensi
b. Otoritas (wewenang)
c. Disiplin 
d. Inisiatif

\section{Penelitian Terdahulu}

a. Penelitian yang dilakukan oleh Yofanda Budi Pratama (2015) dalam penelitiannya yang berjudul " Pengaruh motivasi kerja dan lingkungan kerja terhadap kinerja karyawan pada perusahaan daerah air minum (PDAM) Kabupaten Sleman". Berdasarkan hasil penelitian menjelaskan bahwa Motivasi kerja (X1) memiliki pengaruh positif terhadap kinerja karyawan (Y) PDAM Sleman Kabupaten Sleman, Lingkungan kerja (X2) memiliki pengaruh positif terhadap kinerja karyawan (Y) PDAM Kabupaten Sleman. Hal ini dapat dibuktikan melalui analisis regresi diketahui bahwa pengaruh lingkungan kerja terhadap kinerja karyawan sebesar.

b. Penelitian yang dilakukan oleh Vallent Aflan Dino (2019) dalam penelitiannya yang berjudul "Pengaruh motivasi kerja dan lingkungan kerja terhadap kepuasan kerja karyawan pada PT. JASA RAHARJA cabang Jambi". Berdasarkan hasil penelitian menjelaskan bahwa hasil pengujian data yang telah dilakukan, penerapan motivasi kerja pada karyawan PT. Jasa Raharja Cabang Jambi cukup baik dan karyawan merasa puas. Sedangkan penerapan lingkungan kerja bagi karyawan kurang maksimal, dan Pengaruh motivasi kerja dan lingkungan kerja terhadap kepuasan kerja karyawan PT. Jasa Raharja Cabang 
Jambi, secara simulthan (uji F) kedua variabel tersebut X1 dan X2 sama-sama saling mempengaruhi variabel $\mathrm{Y}$.

\section{Metode Penelitian}

Penelitian ini dilakukan di PT Bank Rakyat Indonesia (Persero) Kantor Cabang Panakukkang Jl. Panakukkang Mas Boulevard No. 16 Pandang Kec. Panakukkang Kota Makassar. Waktu penelitian yang dibutuhkan kurang lebih 1 bulan.

\section{POPULASI DAN SAMPEL}

1. Populasi

Menurut Sugiyono (2016:90) populasi adalah wilayah generalisasi yang terdiri atas obyek atau subjek yang mempunyai kualitas dan karakteristik tertentu yang ditetapkan oleh peneliti untuk pelajari dan kemudian ditarik kesimpulannya.

Populasi dalam penelitian ini adalah seluruh karyawan PT Bank Rakyat Indonesia Cabang Panakukkang Makassar yang berjumlah 30 karyawan.

2. Sampel

Menurut Sugyono (2013:81) sampel adalah bagian jumlah karakteristik yang dimiliki oleh populasi tersebut. Pengambilan sampel dalam peneltian ini menggunakan metode sampling jenuh. Sampling jenuh adalah teknik penentuan sample bila semua anggota populasi digunakan sebagai sampel.

\section{DEFENISI OPERASIONAL}

1. MOTIVASI 
Motivasi merupakan suatu dorongan yang membuat orang bertindak atau berperilaku dengan cara-cara motivasi yang mengacu pada sebab munculnya sebab perilaku, seperti faktor-faktor yang mendorong seseorang untuk melakukan atau tidak melakukan sesuatu.

Motivasi kerja adalah kekuatan dalam diri yang membangkitkan, mengarahkan dan mempengaruhi seseorang untuk memiliki identitas dari ketekunan perilaku sukarela dalam melakukan suatu pekerjaan. Motivasi kerja juga merupakan suatu dorongan psikologis.

\section{SUASANA LINGKUNGAN KERJA}

Lingkungan kerja merupakan salah satu faktor penting dalam menciptakan kinerja karyawan baik ataupun buruk. Suatu kondisi lingkungan dapat dikatakan baik apabila karyawan dapat melaksanakan kegiatan atau pekerjaan secara optimal, tepat waktu, aman dan nyaman. Oleh karena itu lingkungan kerja yang baik akan dapat menentukan keberhasilan dalam mencapai keberhasilan tujuan perusahaan yang di inginkan.

\section{KINERJA KARYAWAN}

Kinerja atau performance merupakan gambaran mengenai tingkat pencapaian pelaksanaan suatu program kegiatan atau kebijakan dalam mewujudkan sasaran, tujuan visi dan misi organisasi yang dituangkan melalui perencanaan strategi suatu organisasi. 


\section{PENUTUP}

\section{Kesimpulan}

Berdasarkan data yang diperoleh dari hasil analisis maka kesimpulan dari penelitian ini adalah sebagai berikut:

1. Motivasi kerja berpengaruh terhadap kinerja karyawan. Hal ini menunjukkan bahwa dengan meningkatkannya motivasi kerja maka kinerja karyawan pada PT. Bank Rakyat Indonesia (Persero) Tbk. Cabang Panakukkang Makassar juga akan semakin meningkat.

2. Suasana lingkungan kerja berpengaruh terhadap kinerja karyawan. Hal ini menunjukkan bahwa semakin baik lingkungan kerja maka akan meningkatkan kinerja kerja karyawan pada PT. Bank Rakyat Indonesia (Persero) Tbk. Cabang Panakukkang Makassar. 


\section{DAFTAR PUSTAKA}

Daga, R. (2021). "Pengaruh Pelaksanaan Program Pemeliharaan Karyawan Terhadap Loyalitas Karyawan Pada Pt. Bank Sulselbar Kantor Pusat Makassar."

Depi Nursiati, 2019. "PENGARUH LINGKUNGAN DAN MOTIVASI TERHADAP KINERJA KARYAWAN PADA BANK BRI SYARIAH KANTOR CABANG MADIUN"

KANTOR, K. P. P. B. S. JUDUL PENELITIAN.

LinovHR, 2020." Motivasi Kerja"

Mashudi, I., Wijiyanti, R., \& Effendi, B. (2020). Pengaruh Motivasi Kerja Kedisiplinan Kerja Dan Lingkungan Kerja Terhadap Kinerja (Studi Kasus pada Karyawan PT. Bank BRI Tbk. Kantor Cabang Kabupaten Wonosobo). Journal of Economic, Business and Engineering (JEBE), 1(2), 319-325.

Nela Pima Rahmawanti, Bambang Swasto, 2014. "Pengaruh Lingkungan Kerja Terhadap Kinerja Kaeyawan (Studi pada Karyawan Kantor Pelayanan Pajak Pratama Malang Utara)" Nur Abib Asrianto, 2013. "Pengaruh Motivasi Kerja dan Lingkungan Kerja Terhadap Kinerja Karyawan CV. Kalika Intergraha Di Semarang" 
Nurjannah ,S., \& Ariyanto ,E. (2016). Pengaruh Motivasi, Pelatihan, dan Lingkungan Kerja Terhadap Kinerja Karyawan Outsourcing Pada PT. Bri, Tbk Kantor Wilayah Jakarta I. Telaah Bisnis Rahmawanti, N. P.(2014). "Pengaruh lingkungan kerja terhadap kinerja karyawan (studi pada karyawan kantor pelayanan pajak pratama Malang Utawa). "Jurnal Administrasi Bisnis, 8(2)"

Sondang P. Siagian (2008:138). "Motivasi Kerja" 